\title{
SZEMLE
}

Educatio 30 (2), pp. 379-383 (2021)

DOI: $10.1556 / 2063.30 .2021 .2 .14$

\section{DiverzitÁs A FELSŐOKTATÁSBAN LEHETŐSÉGEK ÉS KIHÍVÁSOK}

\author{
BAGYURA MÁRTON ${ }^{\mathrm{a}, \mathrm{b}}$ \\ ${ }^{a}$ ELTE Szociológia Doktori Iskola \\ ${ }^{\text {b} E L K H ~ T K ~ S z o c i o l o ́ g i a i ~ I n t e ́ z e t, ~ M T A ~ K i v a ́ l o ́ ~ K u t a t o ́ h e l y ~}$ \\ Beérkezett: 2021. február 15., elfogadva: 2021. március 28.
}

Penny A. Pasque, Noe Ortega, John Burkhardt \& Marie P. Ting: Transforming Understandings of Diversity in Higher Education: Demography, Democracy, and Discourse. Sterling, 2016. Stylus Publishing. xviii + 259 p. DOI: 10.1080/19407882.2019.1631854

A felsőoktatásban dolgozók és tanulók különféle jellemzők szerinti diverzitásának és a kapcsolódó szakpolitikák kutatásának jelentőségét nehéz lenne megkérdőjelezni, hiszen számos társadalmi csoport szenved el hátrányos megkülönböztetést még napjainkban is. A felsőoktatási intézményekbe jelentkezők felvételi esélyei, a hallgatók számára a felsőoktatásban eltöltött évek során az oktatási és közösségi tapasztalatok, a tanulmányok sikeressége és későbbi hasznosulása mind összefüggésben állnak azzal, hogy az állam és az oktatási intézmények hogyan értelmezik és kezelik a diverzitást (Thelin 2011).

Ebben a diverzitásról szóló diskurzusban kívánnak részt venni a Penny A. Pasque, Noe Ortega, John Burkhardt és Marie P. Ting szerkesztésében megjelent tanulmánykötet szerzői, akik különböző demográfiai csoportok példáján mutatják be, hogy a diverzitás milyen jelentőséggel bír a felsőoktatásban. Jóllehet, a szerzők sokféle módon használják a fogalmat, a tanulmányokban közös, hogy a diverzitás kapcsán az egyenlőtlenségekre helyezik a hangsúlyt. A szerkesztőknek céljuk volt, hogy a diverzitásról való gondolkodásba és kutatásba új megközelítéseket és módszereket emeljenek be, a diverzitást és ehhez kapcsolódóan a társadalmi csoportok egyenlőtlenségeit a maguk összetettségében mutassák be. Az új kutatási irányok és eredmények ismertetésének köszönhetően a könyv újdonságokkal szolgálhat a területen tájékozottabb olvasók számára is. A tanulmányok a közérthető megfogalmazás következtében olvasmányosak, a tárgyalt témák sokszínűsége miatt a könyv egésze viszonylag széles körű áttekintést nyújt a diverzitásról, így az még a témában kevésbé jártasak számára is érdekes lehet.

A könyv sajátossága, hogy a diverzitás kutatásának és főleg politikai megítélésének meghatározó tényezőjeként a demokrácia állapotát jelöli meg. Számos fejezet kifejezetten nagy hangsúlyt helyez a demokráciát érő kihívásokra, ugyanis a könyvben megjelenő tanulmányokat áthatja az a gondolat, hogy a különbözőségek elfogadása leginkább demokratikus viszonyok közt lehetséges. A demokráciát a hatalom megosztásával azonosítják, és a 
tanulmányokban gyakran szó esik arról, hogy a hatalom felhasználása és az országra jellemző hatalmi struktúra milyen hatással van a diverzitásra.

A kötet a bevezetésen és a záró tanulmányon kívül tizennyolc fejezetből áll, amelyből kilencet felkért kutatók írtak. Emellett egyetemi hallgatók interjút készítettek a tanulmányok szerzőivel, és az ezekből készült néhány oldalas kivonatok követik az egyes tanulmányokat. A hallgatókat azért akarták bevonni a kötet készítésébe, hogy a pályájuk elején tartó fiatalok és a már tapasztaltabb kutatók közös munkájával is elősegítsék a diverzitást. Az interjúk pedig azért töltenek be fontos szerepet a kötetben, mert segítségükkel képet kapunk arról, hogy a kutatók a diverzitás jelentésének változását hogyan tapasztalták meg saját tudományos pályájuk során, illetve hogy milyen nehézségekkel kellett szembenézniük akkor, amikor a saját kutatóhelyüket igyekezték meggyőzni a téma fontosságáról.

A kötet bevezetőjében a szerkesztők részletesen kifejtik a diverzitás jelentésének, értelmezésének változását az USA felsőoktatásának történetével összefüggésben. Míg korábban a diverzitást jellemzően a faji, etnikai különbözőségekre értették, a fogalmat ma a vallás, a nem, a szexuális irányultság és a társadalmi osztályok kapcsán is használják. A fogalom változó jelentésének megértése nemcsak tudományos jelentőséggel bír, hanem gyakorlati, a hallgatók életét meghatározó következményei vannak. A fogalom jelentésétől függ, hogy a politika és az oktatási intézmények hogyan viszonyulnak a különféle módon meghatározott társadalmi csoportok egyenlötlenségeihez, és hogy milyen intézkedéseket hoznak az egyenlőtlenségek mérséklésére.

$\mathrm{A} z$ egymást követő tanulmányok segítséget nyújtanak a diverzitás és ennek kapcsán az egyenlőtlenségek megértésé- hez azáltal, hogy felhívják a figyelmet azokra a társadalmi csoportokra, illetve az egyenlőtlenségek azon megnyilvánulási formáira, amelyek még kevésbé részei a tudományos és politikai diskurzusnak. $\mathrm{A} z$ alábbiakban röviden összefoglalom a könyvben szereplő tanulmányokban megjelenő gondolatokat, nagyobb figyelmet fordítva az első tanulmányra, amely jól szemlélteti, hogy miért szükséges a diverzitás kutatására és új megközelítések alkalmazására nagy figyelmet fordítani.

$\mathrm{A} z$ első tanulmány $\mathrm{az}$ ún. színvak (color-blind) ideológiát állítja a középpontba a fekete hallgatók diszkriminációját vizsgálva. A társadalompolitikai intézkedések kapcsán ez a színvakság egyfelől pozitív jelentéssel bír, hiszen a célja az, hogy a faji alapú diszkriminációtól mentes legyen, úgy teremtsen esélyegyenlőséget, hogy egy társadalmi csoportnak sem kedvez. Ugyanakkor ez az ideológia és politika azt már nem veszi figyelembe, hogy a történelmileg kialakult egyenlőtlenségek, a diszkrimináció, amit egyes társadalmi csoportok elszenvednek, önmagától, egy mindenkire egyenlően érvényes szabályozástól nem változik meg. A színvak ideológia figyelmen kívül hagyja, hogy a hátrányok leküzdéséhez ezeknek a társadalmi csoportoknak szükségük van további támogatásokra.

Éppen ezért ez az ideológia az egyenlőtlenségek újratermelődéséhez járul hozzá, miközben azt a látszatot kelti, hogy megszűntetésük ellen van. Az ország politikai irányítói és a felsőoktatási intézmények vezetői is szívesen hangoztatják, hogy a mindenkire egyformán vonatkozó szabályozások miatt faji alapú diszkrimináció lényegében nem létezik az oktatási intézményekben. A kutatások ezzel szemben továbbra is kimutatják a feketék hátrányos megkülönböztetését a felsőoktatásban. A színvak ideológia a közgondolkodásban is megjelenik, és sokan a feketék hátrányos 
helyzetének különféle alternatív magyarázatait dolgozzák ki, amelyek függetlenek a diszkriminációtól. Például a feketék hátrányos helyzetét nem a faji hovatartozásukkal, hanem az osztályhelyzetükkel, a szegénységükkel, a feketék saját döntéseivel, cselekedeteivel magyarázzák.

A szerzők kutatási eredményei azt mutatják, hogy a színvak ideológia meghatározza az amerikai fekete hallgatók egyetemi éveinek sikerességét és viszonyukat a többi hallgatóval. Az olvasó számára különösen érdekes, ha a tanulmányban a fekete hallgatókkal kapcsolatban írtakat párhuzamba állítja a magyarországi roma hallgatók helyzetével.

A második tanulmányban a szerzők a demokrácia és a meritokrácia közötti feszültséggel foglalkoznak a felsőoktatásba kerülés vonatkozásában. $\mathrm{Az}$ amerikai felsőoktatásban a felvétel bizonyos érdemek, a hallgatók mérhető teljesítménye alapján történik. Az elemzés szerint ez egy olyan versenyhelyzetet jelent, amelyben elvileg megfelelő tehetség és szorgalom mellett bárki sikeres tud lenni. Valójában a hátrányos helyzetü társadalmi csoportok rosszabb helyzetből indulnak ebben a versenyben, az alacsony jövedelmü tanulók felsőoktatási intézménybe kerülési esélyei rosszabbak, mint a tehetősebb családban élö társaiké. $\mathrm{Az}$ anyagi helyzet alapú egyenlőtlenségre a felsőoktatás kapcsán mégis kevesebb figyelem irányul, mint más (például faji alapú) megkülönböztetésekre, mintha a jövedelem szerinti diverzitás kevésbé lenne jelentős. Mivel a rendszerben fenntartják a tanulók egyenlő elbírálásának látszatát, hiszen azonos módon mérik őket, egyúttal azonban azt már nem veszik figyelembe, hogy az anyagi helyzet milyen hatással van a teljesítményre, így tulajdonképpen ez a rendszer racionalizálja az osztályalapú megkülönböztetést.

A következő tanulmány szerzői kifogásolják, hogy míg a diverzitás tudomá- nyos és (társadalom)politikai használata során a faji, etnikai és nemi (férfiak és nők közötti) különbségekre sok figyelem irányul, addig a szexuális irányultság és a nemi identitás szerinti különbözőségeket nagyon ritkán veszik figyelembe. Ez a hiányosság az esélyegyenlőség megteremtésére irányuló intézkedések esetén is megfigyelhető. Ha a politika vagy az intézmények látóterébe kerülnek is ezek a kisebbségi csoportok, akkor is jellemzően a látványosabb, nyílt diszkrimináció elleni küzdelem a cél. Pedig ma már ez kevésbé jellemző probléma, mint korábban, és az antidiszkriminációs programoknak a figyelmet inkább a kisebb, de a hallgatók eredményességét, életét meghatározó problémák (viccek, megjegyzések stb.) felé kellene fordítaniuk.

A tanulmányban olyan gyakorlatokat és programokat vizsgálnak a kutatók, amelyek az LMBTQ-hallgatók befogadását, jólétét és sikerességét célozzák. Az egyik fontos megfigyelés, hogy a programok a transzneműek jólétével, kirekesztésének megszüntetésével kevésbé foglalkoznak, mint a szexuális orientáció szerinti kisebbségekével. A másik fontos gondolat, hogy a felsőoktatási egyenlötlen helyzetek teljes megértéséhez a felsőoktatási tanulmányok előtti és utáni tapasztalatokat is vizsgálni szükséges, ehhez nyújtanak a szerzők egy maguk kidolgozta kutatási keretet.

A negyedik tanulmány szerzői azokkal a kérdésekkel foglalkoznak, hogy a különböző társadalmi osztályba tartozó, illetve eltérő fajú/nemzetiségű tanulóknak milyen lehetőségeik vannak a felsőoktatásba kerülésre, mennyire határozzák meg ezek a jellemzők, hogy milyen szakot választanak, hogy mennyire lesznek eredményesek. Ennek keretében kutatták azt is, hogy a középiskolás latin-amerikai tanulók hogyan, milyen körülmények között hozzák meg a felsőoktatással kapcsolatos döntéseiket. 
Ezt követően színes bőrű hallgatók felsőoktatási intézményekben szerzett tapasztalatainak vizsgálatára került sor. A kutatás egyedisége abban áll, hogy a faji különbségeket a térről, helyekről való beszéd elemzésével igyekeznek feltárni. A szerző interjúkat készített felsőoktatásban tanulókkal, amelyek során azt tapasztalta, hogy a hallgatók jellemzően nem említettek példákat faji alapú megkülönböztetésre, diszkriminációra. Ilyenről csupán akkor kapott információt, amikor a felsőoktatáshoz köthető terekről, helyekről beszéltek (egyetemi kampusz, kollégium stb.), illetve azok használóiról kérdezte az interjúalanyokat.

A hatodik tanulmány szerzői arra hívják fel a figyelmet, hogy az elmúlt években az amerikai felsőoktatási intézményekben jelentősen megnőtt a fogyatékossággal élő tanulók száma. A szerzők áttekintették a fogyatékossággal kapcsolatos kutatásokat, és arra jutottak, hogy a fogyatékossággal élő hallgatók felsőoktatási részvételéről még kevés ismerettel rendelkezik a tudomány, és hogy a felsőoktatási diverzitásról szóló diskurzusnak nem részei olyan mértékben, mint amennyire jelenlétük alapján indokolt lenne.

A következő tanulmányban a szerzők kvalitatív módszereket alkalmazva azt vizsgálják, hogy a fekete férfi sportoló hallgatók egyetemi pályafutását hogyan befolyásolja a médiában kialakított kép a fekete férfi sportolókról. Az interjúk alapján a szerzők arra jutottak, hogy ezeknek a hallgatóknak nehéz beilleszkedni az egyetemi közegbe, megtalálni és formálni saját identitásukat, mert arra túlságosan nagy hatással vannak a sztereotípiák, hallgatótársaik és tanáraik előítéletei. A sztereotípiák, elöítéletek kialakulása pedig nagyrészben köszönhető a média által a fekete férfiakról konstruált képnek. A fekete férfi hallgatók viselkedését az határozza meg, hogy ezekhez az elöítéletekhez hogyan viszonyulnak.
Az eddigi fejezetek hallgatókról szóltak, a nyolcadik tanulmány viszont a felsőoktatásban már tudományos pályán lévő afroamerikai nők helyzetéről ad információkat. A szerzők azt vizsgálták, hogy ezek az oktató, kutató nők megtapasztalják-e a rasszizmus és szexizmus különféle formáit a hallgatók és a munkatársak részéről. Azt találták, hogy jellemzők az ilyen tapasztalatok, és hogy a megkérdezettek úgy érzik, folyamatosan bizonyítaniuk kell, hogy érdemesek a pozíciójukra. Ez folyamatos feszültséget okoz bennük, fáradtsághoz, stresszhez vezet. Ráadásul ezek a megnyilvánulások gyakran nem is szándékosak, tudatosak, ami jelzi a rasszizmus és a szexizmus látens jellegét.

A $z$ utolsó olyan tanulmány, amelyet a felkért kutatók egyike írt, arra hívja fel a figyelmet, hogy a diverzitás biztosításával a felsőoktatási intézmények célja gyakran sokkal inkább saját legitimitásuk és életképességük megőrzése, mint a társadalmi csoportok közti egyenlőség növelése. Ennek jelentős hatása van arra, hogy milyen intézkedéseket hoznak a kirekesztés és diszkrimináció ellen. A kutatás további érdekessége, hogy a szerző a diverzitás és diszkrimináció kérdését olyan intézmények példáján vizsgálja, amelyekben hagyományosan jellemzően feketék tanulnak, és amelyekről gyakran feltételezik, hogy sokkal inkább befogadók.

$\mathrm{A} z$ utolsó fejezet a könyv összefoglalása, amely visszatér a bevezetőben írt problémához, vagyis a diverzitás konceptualizálásának és operacionalizálásának kérdéséhez. Az írók szerint a diverzitás fogalmának használata nagyon sokféle, és ezt a problémát sokan azzal hidalják át, hogy a fogalmat annyira széles körüen értelmezik, hogy elveszíti jelentését.

Habár a tanulmányok közül több is utal arra, hogy a demokratikus viszonyok hogyan kapcsolódnak a diverzitás kérdéséhez, ezt a kapcsolódást az utolsó fejezet 
teszi egyértelművé. Itt kerül szóba az is, hogy bár a felsőoktatási intézményekben a diverzitás növekedése pozitív fejlemény, ez önmagában még nem változtatja meg az egyes társadalmi csoportokhoz tartozó hallgatók közti egyenlőtlen viszonyokat.

A kötetben megjelent tanulmányok nem mindig kapcsolódnak szorosan egymáshoz, a témák közti váltások során gyakran hiányzik a logikai átvezetés, ugyanakkor a tanulmányok és az interjúkivonatok elolvasása után az olvasó számos szempontot kap a felsőoktatási diverzitás és egyenlőtlenségek értelmezéséhez. A könyv fontos tanulsága, hogy ahhoz, hogy minden hallgató számára azonos tanulási lehetőséget biztosítsunk, a lehető legtöbb szempont szerint és a lehető legmélyebben szükséges megérteni a diverzitást. A kötet arra is rávilágít, hogy új módszerekre és megközelítésekre azért van szükség, mert az egyenlőtlenségek megnyilvánulási formái is folyamatosan változnak.

\section{IRODALOM}

Thelin, J. R. (2011) A History of American Higher Education. Baltimore, Johns Hopkins University Press.

A cikk a Creative Commons Attribution 4.0 International License (https://creativecommons.org/licenses/ by-nc/4.0/) feltételei szerint publikált Open Access közlemény, melynek szellemében a cikk bármilyen médiumban szabadon felhasználható, megosztható és újraközölhető, feltéve, hogy az eredeti szerző és a közlés helye, illetve a CC License linkje és az esetlegesen végrehajtott módosítások feltüntetésre kerülnek. 